\title{
The Ecological Perspective of Chinese Eco-film
}

\begin{abstract}
Xiaolu Wang ${ }^{1, *}$
${ }^{1}$ Communication University of China, Beijing 100024, China

"Corresponding author. Email: wangxiaolu5458@163.com

ABSTRACT

This paper takes Chinese eco-film as the research text, from the cultural psychology of "unity of man and nature", the attitude of "reverence for life", and the ecological appeal of "home consciousness", to observe Chinese eco-film from these three ecological perspectives. As an art style to reflect the real life, the film visualizes the ecological problems in real life into images, and transforms the conceptualized and abstract "relationship between man and nature" in human thinking into clear and perceptible life scenes. Chinese eco-film not only re-examines the relationship between man and nature from the ecological level, it also goes deep into the level of individuation to discuss the multi-faceted and complex nature of human nature, confronting people's survival and spiritual predicaments, and expressing human beings reflection and awareness in internal and external troubles.
\end{abstract}

\section{Keywords: Chinese eco-film, unity of man and nature, reverence for life, home consciousness}

\section{INTRODUCTION}

From the perspective of ecology, we should first understand what Chinese eco-film is. Chinese eco-film emerged in the 1980s. The research scope of eco-film in this paper is the feature film with ecological consciousness. There is a clear definition of eco-film in theoretical circles. In 2004, Harvard University Professor Scott Mac Donald formally put forward the concept of eco-cinema in his paper Toward an EcoCinema, marking the establishment of a formal relationship between ecology and film research. The concept of Chinese eco-cinema was first proposed by Professor Sheldon Lu. "Chinese eco-cinema is a kind of film with ecological consciousness" [1], he wrote in The Possibility of Chinese Eco-Film Criticism. It explores the relationship between human beings and the surrounding material environment, including land, nature and animals. It is a movie that looks at the world from a life centered point of view. First, Sheldon Lu emphasizes that eco-film is regarded as a new research perspective, a new interpretation strategy and a new way of criticism, focusing on the neglected and forgotten ecology and environment themes in life. Second, eco-film is an important part of Chinese films and documentaries. It is a description of a conscious Chinese film.

From the perspective of creative practice, ecological consciousness not only exists in art films and experimental films, but also appears in many other types of film. Some creators have begun to consciously explore the various possibilities of eco-film, and even extend their tentacles to narrative, mainstream and even animated films. From the perspective of the media, the rapid development of science and technology in the new century has led to new changes in the relationship between humans and the media. The different ecological meanings and results formed also affect our understanding of eco-film (and even the film and television form itself). On the material level, there is an inevitable relationship between film and ecology. Therefore, it is necessary to observe Chinese film from an ecological perspective.

\section{THE CULTURAL PSYCHOLOGY OF "UNITY OF MAN AND NATURE"}

In the long history of Chinese traditional culture, the unity of man and nature (天人合一) is one of the most core propositions in Chinese philosophy. The unity of man and nature emphasizes the unity of man and nature, "benevolence person it is an organic whole with works of God" (以天地万物为一) [2], that is, the so-called "between heaven and man, they are one" (天人之际,合而 为一) [3]. From the "heaven of nature" (自然之天) in the pre Qin period to the "Shinto heaven" (神道之天) in the great unification period of the Han Dynasty, Taoism paid more attention to nature and Confucianism paid more attention to man. The unity of man and nature emphasizes the unity of man and nature. It is fundamentally different from the western idea of subject-object dichotomy. It is a blending relationship of "you have me, I have you". In the Doctrine of the Mean, "Let the states of equilibrium and harmony exist in perfection, and a happy order will prevail throughout heaven and earth, and all things will be nourished and flourish" (致中和,天地位焉,万物育焉). Only when all things 
grow harmoniously can we realize the state of harmonious coexistence between man and all things. Nature makes all things in the universe full of lift, and human beings are full of vitality. The unity of man and nature will bring the aura of heaven and earth into one. The category of unity of man and nature connects nature with human beings. Here, nature does not only refer to the natural sky, but also has rich connotations, which can not be generalized.

Unity between man and nature regards the relationship between man and nature as a whole, which embodies the primitive ecological holistic view. Book of Changes regards heaven, earth and man as "three talents" (三才). The world system constructed by the eight trigrams (八卦) and the sixty-four hexagrams (六十 四卦) is composed of heaven, earth and human beings, so as to grasp the world as a whole. The unity of man and nature breaks through the boundary between phenomenon and noumenon, individual and general, thus realizing the supreme state of the unity of man and nature, which is similar to Heidegger's "dwelling in the land of poetry on".

Heidegger thinks that human being "in the world" is "I live in the world, I take the world as such and so to depend on, stay in it" [4]. He believes that the relationship between man and nature is not antagonistic, but participatory and intergrowth. Nature exists as a home (not a landscape to be watched). As the home of human beings, the earth is not only a space in the geographical sense, but also a phenomenon of world, in which people are not the masters of the world or bystanders, but residents at home. The nature understood by Heidegger is similar to the natural " $\varphi \cup \sigma \mathrm{l}$ $\varsigma^{\prime \prime}$ understood by the Greeks. It is the original nature, the process of nature, the unity of heaven, earth, man and god, the ecological and poetic spiritual home, the unity of "the being of nature" and "transcendental being itself". Heidegger advocated "dwelling in the land of poetry on". "All labor and activities, construction and care are 'culture'. And culture is always and always the result of a kind of dwelling. This kind of dwelling is poetic"[5]. Heidegger believes that truth, goodness and beauty are hidden in the depths of things, and art can unmask the hidden truth. The way of aesthetics is a kind of free liberation, allowing all things in nature to return to the earth (he called "the things that appear in the return of the work" the earth).

In some film and television works, the creator gestates the overall ecological view, it presents the realm of "things and me as one" (物我一体) (mostly refers to the wilderness rather than the city) between the individual and nature. In Gada Meilin, with the attitude of "dwelling in the land of poetry on", Gada Meilin regards Mongolian grassland as a residence closely related to human beings. Gada Meilin did not oppose nature and himself, but integrated himself into nature. The simple and perfect concept of nature is vividly revealed in Gada Meilin. He took the children to gallop freely on the grassland. Gada Meilin creates an ecological picture of nature and human beings living in harmony. This harmonious relationship is not in man or nature, but in the interaction between man and nature. The Mongolian grassland has a good ecosystem. Humans and other life in nature are part of the ecosystem, and all parts are interconnected and coordinated with each other. The flowers, leaves, grasses and trees in the Mongolian grasslands are full of the poetic existence of the harmony between man and nature. And this peaceful state of unity of man and nature and "things and me as one" can only be experienced in nature.

Unity between man and nature develops harmoniously with nature on the basis of relying on nature. Heaven, earth and all things are a harmonious and orderly universe family, and human beings are one of them. Only in all things can humans show their value. This value exists in the process of transforming and nurturing life. We are in an environment with extremely bad ecological conditions. Human beings are destroying nature with their own hands. Therefore, the beautiful picture presented by the ecological wisdom of unity between man and nature is not so much advocating people to enjoy ecological beauty, but rather expressing the call and yearning for ecological beauty.

\section{THE ATTITUDE OF "REVERENCE FOR LIFE"}

First of all, the reverence for life holds that all things are created equal. Lao Tzu believes that "One is the child of the divine law. After one comes two, after two comes three, and after three come all things." (道生 一,一生二,二生三,三生万物) [6]. The total root of all things lies in "the divine law"(道). The divine law is the beginning of heaven and earth, the mother of all things. The divine law derives "yin" (阴) and "yang" (阳), creating the universe and earth. From the perspective of the origin of all things, man and nature all come from the divine law, and their essence is the same, so we should respect all things equally. Here, Lao Tzu raised man to the same status as heaven, earth and the divine law, affirmed the value of man, and at the same time denied the idea of taking human as the absolute center. Lao Tzu emphasizes that the scope of the laws of nature is extremely broad, and believes that the heavens and the earth exist on an equal basis with human beings. Although there are differences in external mechanism between different species, their internal values are equal. Other life and heaven and earth occupy the same important position in the universe, so they should be treated with the same respect. Chuang Tzu put forward that "heaven and earth coexist with me, and all things 
and I are one"(天地与我并生,而万物与我为一) [7], believing that all things and I are the same and can be integrated into one, which also denies the concept of anthropocentrism. Chuang Tzu believes that the origin of everything is the same. There is no distinction between high and low, and looking at things based on one's own standards will lead to "valuing oneself and neglecting things" (贵己轻物). People should treat other species in nature with an equal attitude and respect the survival value of other species, instead of focusing on human self-centeredness, only emphasizing their own development, regardless of the survival and development of other species. Here Chuang Tzu has seen that the value judgment of things is based on the subject, and that human beings use themselves as the measure of all things, which will inevitably lead to narrow anthropocentricism. Taoism examines the relationship between man, nature and everything from a broad perspective.

The movie Wolf Totem, starred by Feng Shaofeng, embodies this concept of equality. The wolf is the patron saint of the Elun Prairie, the belief of the grassland people, and the companion of people, teachers and friends, and the holy spirit with divinity. The life of wolf, man, sheep and dog is not static and isolated, but interdependent and coexisting with each other. Without the support and maintenance of nature, life is difficult to evolve and develop healthily. This is quite different from the opposition between man and nature in anthropocentrism. It dispels the humancentered concept. There is a holistic relationship between humans and natural ecology. People and things in the universe all influence and relate to each other. Human beings can not only think from their own standpoint, but also reflect on themselves from the standpoint of others. This is a unique ecological feeling. Similarly, Mountain Patrol also embodies the reverence and care for life. In the process of chasing poachers, the members of the patrol team fought desperately with nature. The relationship between man and nature determines the contradiction between man and nature. Lu Chuan tells the relationship between man and nature by showing the story between man and man. Relations reflect the fear and reverence of human beings for nature through human behaviors, thoughts, and beliefs. In the film, the mountain patrol team recognizes the value of other lives (Tibetan antelope), regards the suffering of wild animals as their own suffering, empathizes with other lives, recognizes the value of the existence of others, and eliminates the distance between different lives. In this aesthetic relationship, this concept is similar to the ethical concept of respect for life by Western ecological ethicist Schweitzer.

Secondly, reverence for life emphasizes reverence for nature and respect for nature. Confucius said, "There are three things of which a superior man is in awe. He is in awe of the will of Heaven. He is in awe of great men. He is in awe of the words of sages" (君子有三 畏：畏天命、畏大人、畏圣人之言) [8]. Although it contains a strong mystery, it contains awe of the heavens and the earth. Confucius regards heaven as an objective existence not based on human will. It shows the ancient people's yearning and pursuing for nature. On this basis, Mencius aroused the love and concern for animal life, "When you've seen how birds and animals live, you cannot bear to see them killed; when you've heard how birds chirp and animals cry, you cannot bear to eat their meat"（君子之于禽兽也，见其生，不忍见其死，闻其声，不忍

食其肉） [9]. The care and love for animals is unconsciously revealed in Mencius, and he has awe of life. The concern for nature is also the concern for human beings. It is necessary not only to treat people with humanity, but also to extend it and treat all things in the world with the same attitude. Respect and conform to nature, and cultivate according to changes in nature. In accordance with the farming season, the number of fish should not enter the pond, and the axe should enter the mountain forest at the right time, so that the animal can live and die without regret [10]. In the process of connecting with the natural environment, it is necessary not only to protect it, but also to create favorable conditions to promote the common development of nature and man. In Return To The Wolves, the little wolf Green grows from a little wolf cub to a wild wolf. He has learned to use the remote control to watch TV, and learns the Tibetan mastiff's barking. Green brought fresh food when Li Weiyi was ill. Yifeng suggested to take Green home, while Li Weiyi insisted on sending Green back to nature. Yifeng asked her, "Since you are so reluctant, why not take it home and raise it for a lifetime?" Li Weiyi replied, "Wolves are not dogs, the wolf's nature is freedom." This is respect for Green and nature, not just sympathy for life. The nature of the wolf is freedom. To return the wolf to nature is a respect for the way of heaven and the best interpretation of reverence of nature. In contrast, the film Wolf Totem also responded to this theme. In the novel, Chen Zhen ended the life of the little wolf, while in the movie Chen Zhen put the little wolf back into nature, looking for his spiritual home. It also reflects the harmonious coexistence between man and nature, and man's awe of nature.

Thirdly, reverence for life emphasizes "natural inaction" (自然无为). Lao Tzu said, "For I am abstracted from the world, the world from nature, nature from the way, and the way from what is beneath abstraction" (人 法地，地法天，天法道,道法自然) [11]. The nature here is not the term nature, but the essential state of things naturally. The development of things follows the divine law, which is the nature of things. As a branch of all things, it is difficult to separate man from nature. If human beings want to coexist harmoniously with 
nature, they cannot change the development process of things with their subjective will. If humans want to change, they can only accept the tragedy they have caused. This is the deepest ecological wisdom of Taoism. Natural inaction is not doing nothing, but respecting objective laws and not forcibly interfering with the essence of things. Similarly, Chuang Tzu also agrees with this idea. The law of things can not be changed by human will. Only when they conform to the growth law of the universe, can everything grow and develop. What mankind does to nature, nature will repay mankind. People don't plant crops seriously, and crops reward you with bad harvests. If human beings don't weed seriously, the grass will respond to you roughly. If human beings work hard and pull weeds carefully, they will have no worries about food and clothing for a year. The best way for human beings to treat other lives well is to let their inaction grow, so that man and nature can achieve the ultimate harmony. The ecological wisdom of Taoism has subtly influenced the Chinese people's concept of the universe. They believe that heaven and earth are interconnected with people. Although man is not the scale of all things or the primate of the universe, as a creature with a higher degree of evolution in the ecosystem, it should take the responsibility of maintaining the ecology. Wolf Totem embodies this concept of natural inaction. In the Elun Prairie, wolves use objective natural conditions such as terrain and weather to capture prey by collective action. On the grassland, humans and wolves coexist. The "wolf way" is the "heaven way". Wolves kill the grassland destroyers such as yellow sheep and hare, devours the carrion left on the grassland, and converts it into organic fertilizer (wolf dung). Wolf, as the king of grassland, maintains the ecological balance of grassland and composes the grand historical picture of grassland ethnic group together with people. To respect wolves means to respect the natural development of grassland, and maintain the balance of ecosystem according to its own laws.

\section{THE ECOLOGICAL APPEAL OF "HOME CONSCIOUSNESS"}

\section{A. Understanding of home consciousness authors and affiliations}

Since ancient times, Chinese traditional culture has contained a strong sense of home and has gradually evolved into a cultural tradition. This tradition is the Chinese people's longing for their home and their longing for living and working in peace and contentment after suffering and wandering. Home refers to both the natural home and the spiritual home. This complex emotion is not innate or self-evident, on the contrary, it is constructed by complex cultural habits and national psychology. In Daya Mian, Zhou people need fertile land and rich resources to settle down. Facing the rolling waves of the Yellow River, the wanderer would like to drive a reed home. Li Bai's famous saying, "on a quiet night I saw the moonlight before my couch, and wondered if it were not the frost on the ground. I raised my head and looked out on" (床 前明月光,疑是地上霜。举头望明月，低头是故乡), also shows the important position of home in the hearts of Chinese people.

The earliest home consciousness in the West can be traced back to the Homer Epic in ancient Greece. Odysseus returned to his hometown after ten years, implying that human beings can only return to their spiritual home through hardships and dangers. Plato's home is the eternal world of ideals in The Republic. The ancestors of mankind Adam and Eve were expelled from the Garden of Eden for eating the forbidden fruit. The Garden of Eden is a cultural symbol of Western home consciousness. The industrial revolution accelerated the collapse of the natural environment, and the spiritual world of people became more anxious. Western people's home consciousness is strongly impacted, and human beings generally have a sense of loss of home. In Heidegger's view, home refers to such a space, which endows people with a place in which they can feel at home and thus exist in the essential elements of their destiny [12]. Home is a kind of space and the guardian of the relationship between the world and human beings. What is still well preserved is home in its essence. It illuminates the human mind and makes the human mood open to the true meaning of fields, towns and homes[13]. After modern science and technology occupy the human world, people's survival foundation has encountered a huge threat. People have lost their hometowns, were expelled from their hometown, joined the urban famine. Holmes Rolston discusses the home consciousness from the perspective of ecological aesthetics. He thinks, "I define the landscape I live in as my home. This interest leads me to care about its integrity, stability and beauty" [14]. He believes that the sense of human identity should be expanded into the local and local biological community.

When the world gradually becomes a village, the differences between regions are gradually narrowing, and the culture is constantly merging, globalization is constantly impacting the home consciousness. Eco-film is full of utopian colors, fantasizing about returning to their home. Humans compete with mobility, insecurity, and lack of belonging. As an important part of contemporary ecological aesthetics, home consciousness not only contains the relationship between human and natural ecology, but also contains the true meaning of "dwelling in the land of poetry on". Professor Zeng Fanren of Shandong University wrote in

On "Home Consciousness" - the Core Category of Contemporary Ecological Aesthetics, "'Home consciousness' embodies the theoretical characteristics 
of contemporary ecological aesthetics as ecological ontological aesthetics, reflects the fundamental difference between ecological aesthetics and traditional aesthetics, and becomes the core category of contemporary ecological aesthetics". It is different from the epistemological relationship between man and nature in traditional aesthetics, but is based on the harmonious and unified existential relationship between man and nature. Man is not outside of nature, but in nature. Nature is the home of human beings, and man is a member of nature.

\section{B. The embodiment of home consciousness in eco-film}

At a shallow level, home consciousness refers to the place where human beings live, which is the material basis for human reproduction and life. It reflects the meaning of human protection of home and respect for the ecological environment. From a deep level, home consciousness represents the salvation of human beings for themselves. Human beings are on the way of returning and emancipating the soul, making the spirit and soul return to the original brightness and clarity. Home consciousness has two ways of expressing in the film, which will be illustrated by examples below.

The first expression of home consciousness is to show the loss of home. The industrial revolution made the city expand continuously, and the entry of capital stimulated man's desire for money. Human beings are using nature as collateral in exchange for money. In 1978, William Ruecker pointed out in his paper Literature and Ecology: An Experiment in Ecocriticism, that we are destroying our home ecosphere. The inhabitants of the earth, regardless of their ethnic or cultural background, are interdependent and share a global eco-system. Eco-film is not only to show the current situation of rural life, but also to express an ecological consciousness. In Gada Meilin, the grassland hero Gada Meilin protects the Horqin grassland where he breeds herdsmen. He raises the banner of resistance and sacrifices his life. Regrettably, the disappearance of Horqin Grassland can no longer be retrieved.

The second expression of home consciousness is human beings' self-consciousness and salvation. Home consciousness comes from the criticism of the real environment, and is a reflection of entertainment culture and consumer culture to a certain extent. Human beings put themselves in the environment of money for a long time. They were brainwashed by the secular world and lost the peace and tranquility of spirit. In Mermaid, Liu Xuan, as a billionaire, became invincible loneliness when he stood at the top of the world. Zhou Xingchi uses the story of Liu Xuan and the mermaid to reveal from the side that human progress is built on threatening other lives and destroying the ecological environment, which is not a sustainable development.
After experimenting with sonar system, he realized how shameless and unbearable his behavior was. He realized that the investment in ocean real estate hurt other lives, and realized the loneliness of human beings. This kind of empathy conveys a deep-seated humanistic pursuit. Eco-films reflect a world of natural balance. It express people's desire to return to nature. The word return in the title of Return to the Wolves has a profound meaning and contains multiple meanings. Green needs to leave the human world and return to the embrace of nature. At a deeper level, human beings also need to return to the era of respect for ecology and life, return to the state of harmony between man and nature, and return to the inner spiritual home, that is, by exploring the goodness in human heart to realize the identity between man and nature. Li Weiyi took Green back to the Zoige grassland and helped Green find the wolves. As a gregarious animal, the acceptance of new members by wolves has the significance of group survival. Li Weiyi trained Green to catch mice, learn to be afraid of people, and lead Green to move from the city to nature, from the kindness of domestication to the rationality of wildness, which highlights the spiritual height of people returning to their natural home.

\section{CONCLUSION}

To sum up, the content of Chinese eco-film shows the relationship between man and nature, man and society, and man and man, reflecting the hidden problems in the process of industrialization and urbanization, and reflecting the survival of modern people from different angles, advocating people to return to their spiritual home. Since the 19th National Congress of the Communist Party of China, China has entered a new era. How to spread ecological concepts in the current cultural context, how to discover new themes, content, and themes, and how to create a unique aesthetic style for eco-film, not only need to summarize the past experience and learn from the ideas of other countries, but also need the creators to examine the current cultural ecological environment, find a balance between ontological value and social function, and integrate humanistic care and ecological philosophy.

\section{References}

[1] Lu Xiaopeng, and Tang Hongfeng,The Possibility of Ecological Criticism of Chinese Cinema,Literature and Art Research,2010, vol. 7, pp.92-98

[2] Sun Fuwan,The benevolent, with the world and all things as one, Guangming Daily, 2016.12.8, 6th edition.

[3] Zhang Shiliang, and Zhong Zhaopeng,Chun Qiu Fan Lu, Zhou Guitian translation and annotation, Beijing: Zhonghua Book Press, 2012, p. 369

[4] Heidegger, Existence and time. Beijing: Beijing Sanlian Bookstore Press, 2006, p. 64. 
[5] Heidegger:,An Interpretation of Holderlin's Poems, Beijing: The Commercial Press, 2000, p. 107.

[6] Wang Bi:,Lao Tzu's Commentary on the Dao De Jing,Beijing: Zhonghua Book Press, 2008, p. 117.

[7] Yangliuqiao:,Zhuangzi's Translation and Annotation, Shanghai: Shanghai Ancient Books Publishing House Press, 2006, p. 31.

[8] Huang Kan,On Semantics, Beijing: Zhonghua Book Press, 2013, p. 431.

[9] Jin Liangnian,Mencius Translation and Annotation, Shanghai: Shanghai Ancient Books Publishing House Press, 2004, p.14.

[10] Jin Liangnian,Mencius Translation and Annotation, Shanghai: Shanghai Ancient Books Publishing House Press, 2004, p.5.

[11] Yangliuqiao:,Zhuangzi's Translation and Annotation, Shanghai: Shanghai Ancient Books Publishing House Press, 2006, p. 64.

[12] Heidegger:,An Interpretation of Holderlin's Poems, Beijing: The Commercial Press, 2000, p. 15.

[13] Heidegger:,An Interpretation of Holderlin's Poems, Beijing: The Commercial Press, 2000, p. 18.

[14] Arnold Berlint,Environment and Art: A Multidimensional Perspective of Environmental Aesthetics, Chongqing: Chongqing Publishing Press, 2007, p. 140. 